INSTITUTE OF FORESTRY • BELGRADE

INSTITUT ZA ŠUMARSTVO • BEOGRAD

SUSTAINABLE FORESTRY

ODRŽIVO ŠUMARSTVO

COLLECTION 73-74, 2016

ZBORNIK RADOVA 73-74, 2016

UDK 630*232.12+630*165.3:582.475(497.11) $=111$

Original scientific paper

\title{
VARIABILITY OF THE WIDTH OF DOUGLAS- FIR (Pseudotsuga menziessii /Mirb./Franco) NEEDLES IN PROVENANCE TESTS
}

\author{
Vera LAVADINOVIĆ ${ }^{1}$, Vukan LAVADINOVIĆ ${ }^{2}$, Zoran PODUŠKA ${ }^{1}$, \\ Milan KABILJO ${ }^{1}$
}

\begin{abstract}
Introduced tree species which have a wide natural range of distribution should be tested in experiments with different provenances. Douglas-fir is a very productive conifer species in its natural forest stands of America and Canada. Because of its high value, it is very popular in the countries of Europe and New Zealand as a conifer species suitable for reforestation. Its genetics and ecological adaptability can be confirmed by the investigations of its variable morphological traits, which is the aim of this research. Needle characteristics and needle morphology play a very important role in the performance of plant functions. Needle structure has a great influence on the plant life-cycle and their resistance to water loss, temperature and $\mathrm{CO}_{2}$ levels. The characteristics and morphology of needles were studied in order to determine whether there are differences between the provenances. Two experimental plots with twenty Douglas-fir provenances originally from North America were established in Serbia. A two-way analysis of variance was aimed at a closer study of the effects of the interaction of the site conditions of Douglas-fir provenances in the test locations in Serbia on the morphological traits of the needles.
\end{abstract}

Keywords: Douglas-fir, provenance, width of needles

\section{VARIJABILNOST ŠIRINE ČETINA DUGLAZIJE (Pseudotsuga menziessii /Mirb./Franco) U PROVENIJENIČNIM TESTOVIMA}

Izvod: Introdukovane vrsta drveća, koje imaju širok spektar prirodnog areala, treba da bude testirane u ogledu sa različitim provenijencijama. Duglazija je veoma produktivna četinarska vrste u svojim prirodnim šuma Amerike $i$ Kanade. Zbog svoje visoke vrednosti ona je najpopularnija u zemljama Evrope i Novom Zelandu, kao

\footnotetext{
${ }^{1}$ Institute of Forestry, Kneza Višeslava 3, Belgrade, Email: veralava@eunet.rs

${ }^{2}$ Faculty of Forestry, Kneza Višeslava 1, Belgrade
} 
odgovarajuća vrsta četinara za potrebe pošumljavanja. Genetika i ekološka adaptivnost mogu biti potvrdjeni ispitivanjem morfoloških promenljivih karakteristika, koji su i cilj ovog istraživanja. Karakteristike i četina i morfologija je veoma važna za biljne funkcije. Struktura četina su sa značajnim uticajem na životni ciklus biljaka i otpornost na gubitak vode, balans temperature i nivoa $\mathrm{CO}_{2}$. Karakteristike četina i morfologija, analizirani su u cilju da prepoznaju da li postoje razlike između istraživanih provenijencija. Dva eksperimentalna ogleda sa dvadeset provenijencija duglazije su osnovana u Srbiji sa orginalnim semenskim materijalom iz Severne Amerike. Dvofaktorijalna analiza varijanse imala je za cilj bliže ispita efekta interakcije uslova staništa provenijencija duglazije $u$ ogledima u Srbiji na morfološke karakteristike četina.

Ključne reči: Duglazija, provenijencija, širina četina

\section{INTRODUCTION}

Intense climate change has threatened natural regeneration of ecosystems and native species are losing the optimum conditions under which they can survive. The changing water regimes, temperatures and soil structure have inevitable implications for vegetation. Therefore, the adapted reforestation strategy should consider the introduction of adaptive and promising tree species as one of the possible solutions. Introduction of trees include adaptation, productivity and successful growth in new environmental conditions.

If a species has a wide natural range of distribution, it is important to choose the most appropriate provenance. Successful introduction requires the control of genetic material and its testing by provenance test (Rehfeld, G.E. 1989).

Douglas-fir (Pseudotsuga menziessii /Mirb./ Franco) is the most successful and ecologically-adapted introduced species in Europe (Hermann, R. K. 1987). It was introduced into Europe in 1825 by a Scottish botanist David Douglas (Allen, GS, Owens, J. N. 1972). Its natural range extends from British Columbia in the north as far as New Mexico in the south (Allen, G.S., 1942; Alexander, R.R. 1988). More genetics research is being done on Douglas-fir than any of its associates (Adams, W.T., et al. 1990; Bialobok, S., Mejnrtowicz, L. 1970; Campbell, R.K. 1979, 1992; Campbell, R.K., Sugano, A.I. 1993; Erikson, G., Ekeberg, I. 2001; Nicholas, D.Dean 1963; Rehfeld, G.E. 1989; Wright, J.W., et al. 1971).

Adaptation of introduced species to new environments is one of the greatest challenges to forest trees (Arno, S.F. 1990). Of all strategy questions regarding Douglas-fir, long-term adaptation causes the most serious concern. No geneticist will ever be able to use as expensive and effective methods, involving virtually infinite time and numbers of trees, as were employed in natural selection for adaptation to the local environment and climate. Genetically improved and locally adapted Douglas-fir, confined to favorable sites, should contribute significantly to the economy of temperate zone forests of the world. (Silen, R.R., 1978).

The main parts of the plant water transpiration system are located in leaves. Needle characteristics and needle morphology play a very important role in the performance of plant functions. Needle structure has a great influence on the plant life-cycle and their resistance to water loss, temperature and $\mathrm{CO}_{2}$ levels. The analysis of morphological and anatomical characteristics of needles can be a 
significant indicator of the ecological adaptability of introduced species to new sites. Identification of these characteristics is important for the description of the plant reaction to environmental stress. It is important to realize that genetic variation and differentiation may represent alternative modes of adaptation to diverse environmental conditions. (Martha E. Apple et al. 2000; Urbaniak, Kalinski L, R Popielarz, 2003). The aim of the study was to compare the mean width of Douglas-fir needles of different provenances in order to determine whether there are variations in the morphology of Douglas-fir needles from two sites in Serbia.

\section{MATERIALS AND METHODS}

The research area included Douglas-fir provenances of different locations originating from the natural range of this species in North America. The geographical coordinates of the tested provenances are shown in Table 1 below.

The original Douglas-fir seeds of different provenances (Table 1 `Number of provenance') were used to produce seedlings and set up two experiments at different sites. One experiment was set on Mount Juhor (central Serbia) on the site of mountain beech forests (Fagetum moesiaca montanum Jov. 1976- Jovanović, B. 2000) and the other in Tanda near Bor (eastern Serbia) on the site of Hungarian oak and Turkey oak forests (Quercetum frainetto-cerris Rud. 1949- Jovanović, B. 2000). The field experiments were based on the principle of the 'random block system ' (a randomized block design with a random arrangement of provenances). The experiments were part of long-term research on the properties of Douglas-fir (Lavadinović, V., Koprivica, M. 1996, 1999, Lavadinović, V., Isajev, V. 2003).

Table 1. Geographical coordinates of the tested Douglas-fir provenances

\begin{tabular}{|l|c|c|c|c|}
\hline \multicolumn{1}{|c|}{$\begin{array}{c}\text { Identification Number of } \\
\text { Provenance }\end{array}$} & $\begin{array}{c}\text { Our } \\
\text { mark }\end{array}$ & $\begin{array}{c}\text { Latitude } \\
\left({ }^{\mathbf{}} \mathbf{N}\right)\end{array}$ & $\begin{array}{c}\text { Longitude } \\
\left({ }^{\mathbf{C}} \mathbf{E}\right)\end{array}$ & $\begin{array}{c}\text { Altitude } \\
(\mathbf{m})\end{array}$ \\
\hline \hline Oregon 205-15 & 1 & 43.7 & 123.0 & 750 \\
\hline Oregon 205-14 & 2 & 43.8 & 122.5 & 1200 \\
\hline Oregon 202-27 & 3 & 45.0 & 122.4 & 450 \\
\hline Oregon 205-38 & 4 & 45.0 & 121.0 & 600 \\
\hline Washington 204-07 & 9 & 49.0 & 119.0 & 1200 \\
\hline Oregon 205-13 & 10 & 43.8 & 122.5 & 1050 \\
\hline Oregon 205-18 & 11 & 44.2 & 122.2 & 600 \\
\hline Oregon 202-22 & 12 & 42.5 & 122.5 & 1200 \\
\hline Washington 202-17 & 15 & 47.6 & 121.7 & 600 \\
\hline Oregon 201-10 & 16 & 44.5 & 119.0 & 1350 \\
\hline Washington 201-06 & 17 & 49.0 & 120.0 & 750 \\
\hline Oregon 202-19 & 18 & 45.3 & 123.8 & 300 \\
\hline Washington 204-09 & 19 & 49.0 & 119.3 & 900 \\
\hline Oregon 205-11 & 20 & 45.0 & 123.0 & 150 \\
\hline New Meksiko 202-04 & 22 & 32.9 & 105.7 & 2682 \\
\hline New Meksiko 202-10 & 23 & 36.0 & 106.0 & 2667 \\
\hline Oregon 202-31 & 24 & 44.3 & 118.8 & 1500 \\
\hline Oregon 205-29 & 26 & 42.6 & 122.8 & 900 \\
\hline Oregon 204-04 & 30 & 45.0 & 121.5 & 900 \\
\hline Washington 205-17 & 31 & 47.7 & 123.0 & 300 \\
\hline
\end{tabular}

For the analysis of the morphometric traits of Douglas-fir needles at the two sites, only the samples of selected provenances were taken. The selection of the 
provenances from which the needles would be taken was done on the basis of the results obtained in the study of the variability of growth elements (Lavadinović, V. Koprivica, M. 1999). The samples were taken from two provenances whose trees had minimum, average and highest mean values of the studied growth elements. Fresh needles were fixed in 50\% ethyl alcohol and transported to the laboratory where permanent anatomical sections of 30 randomly selected needles were made. The permanent anatomical preparations were cut using a microtome at $17 \mu \mathrm{m}$ thickness in the middle of the needle, then stained with Safranin red and Toluidine blue and washed with water, after which the ethyl alcohol dedehydration was applied increasing the alcohol concentration from 50\% to $96 \%$. The fixation of the sections was completed with xylene for a period of several hours, after which the needles were glued to glass with Canada balsam, glass covered and dried in an oven at a temperature of $60^{\circ} \mathrm{C}$.

\section{RESULTS AND DISCUSSION}

\subsection{The two-way analysis of variance for the width of needles}

As can be seen from the results of the analysis of variance shown in Table 2:

a) there are statistically significant differences in the mean values of the width of Douglas-fir needles of the Juhor site and the Tanda site;

b) there are statistically significant differences in the mean values of needle width between the provenances of the same site;

c) with certain provenances, the interaction between the 'site' and 'provenance' factors affects the mean width of the needles.

Table 2. The two-way (site of $X$ provenances) analysis of variance for the width of needles

\begin{tabular}{|l|c|c|c|c|c|}
\hline $\begin{array}{c}\text { Source } \\
\text { of variation }\end{array}$ & Sum of squares & $\begin{array}{c}\text { Degree of } \\
\text { freedom }\end{array}$ & Variance & F- ratio & p-value \\
\hline \hline A: Site & $1.38756 \cdot 10^{6}$ & 1 & $1.38756 \cdot 10^{6}$ & 334.27 & 0.000 \\
\hline B: Provenance & $3.37372 \cdot 10^{6}$ & 5 & 674743.0 & 162.55 & 0.000 \\
\hline Interaction AB & $3.53721 \cdot 10^{6}$ & 5 & 707441.0 & 170.42 & 0.000 \\
\hline Error & $1.44457 \cdot 10^{6}$ & 348 & 4151.08 & & \\
\hline Total & $9.74306 \cdot 10^{6}$ & & \\
\hline
\end{tabular}

\subsection{The impact of the site on the needle width}

The least significant difference test was used to determine the impact of environmental factors of a site on the variability of the width of Douglas-fir needles. 
Table3. LSD test of the impact of the sites of Juhor and Tunda on the needle width

\begin{tabular}{|c|c|c|c|c|}
\hline Site & Sample size & Mean value & $\begin{array}{c}\text { Error of mean } \\
\text { differences }\end{array}$ & $\begin{array}{c}\text { Homogeneous } \\
\text { groups }\end{array}$ \\
\hline Juhor & 180 & 1396.75 & 4,80224 & $\mathrm{X}$ \\
\hline Tanda & 180 & 1520.92 & 4,80224 & $\mathrm{X}$ \\
\hline Comparison & \multicolumn{3}{|c|}{ Differences } & \\
\hline $\begin{array}{r}\text { Juhor-Tanda } \\
13.3574\end{array}$ & \multicolumn{3}{|c|}{$*-124.167$} & \\
\hline
\end{tabular}

* indicates statistically significant differences

The presented data (Table 3) show that there are statistically significant differences in the mean width of Douglas-fir needles between the sites of Juhor and Tanda. The average width of the needles in Tanda $(1520.92 \mu \mathrm{m})$ is significantly higher than on Juhor $(1396.75 \mu \mathrm{m})$, and the test confirms the impact of environmental factors of these two sites on the differences in the size of needles. The obtained data are graphically represented (Graphs 1 and 2).

\subsection{The impact of provenances on the needle width}

Table 4. LSD test of the impact of provenances on the width of needles

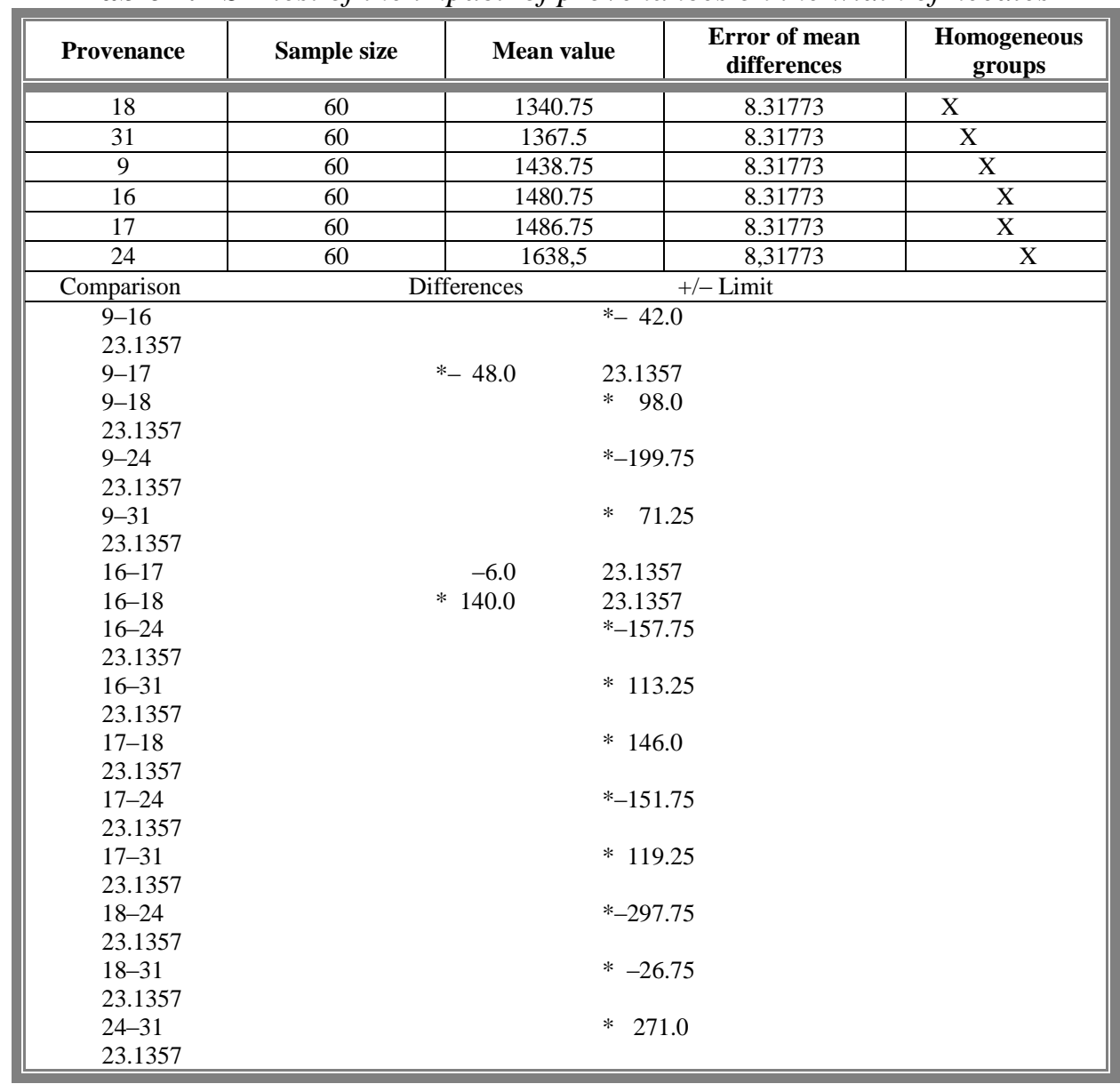

* statistically significant difference. 
Although Table 4 of the analysis of variance clearly shows that there are statistically significant differences in the width of needles between certain provenances, LSD test shows that some provenances (16 and 17) are homogeneous in this character, i.e. the differences in the mean values of the needle widths are not significantly different.

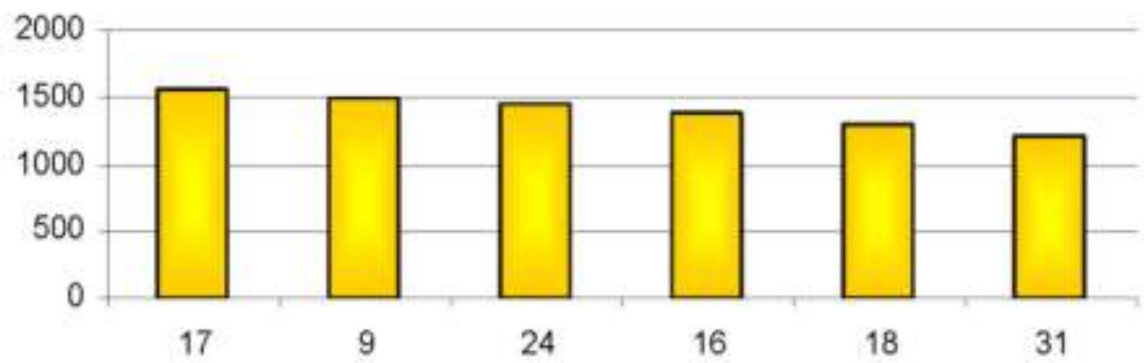

Provenance

Graph1. Interprovenance variability of the needle width at Juhor site

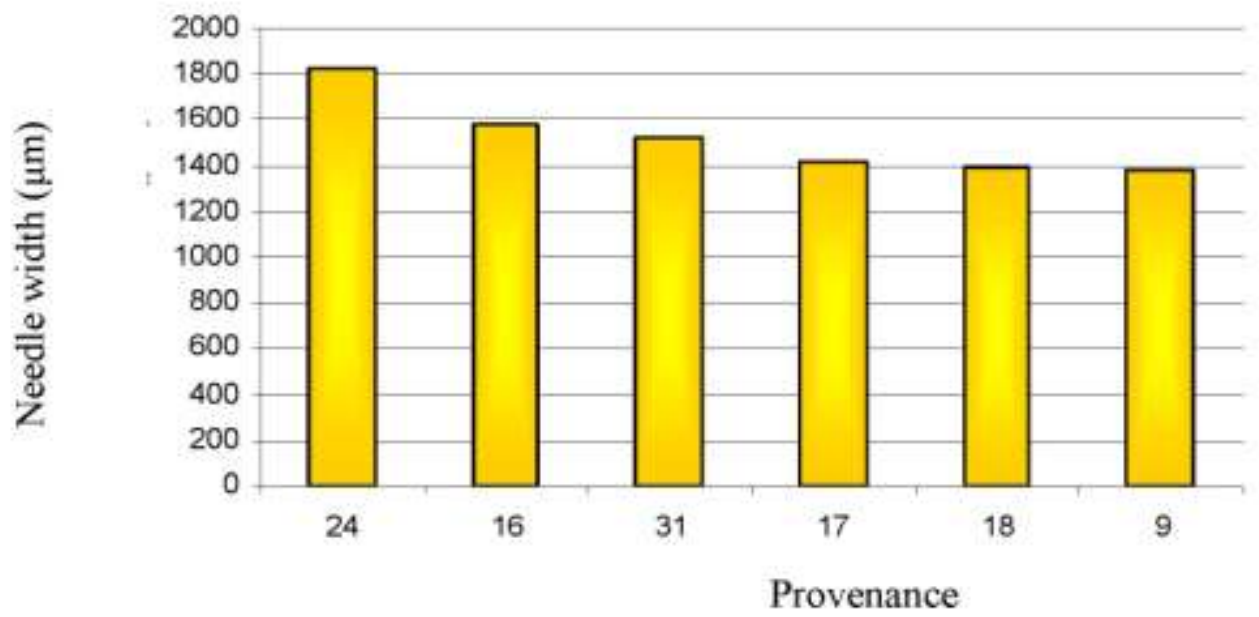

Graph 2. Interprovenance variability of the needle width at Tanda site

\section{CONCLUSION}

Douglas-fir is a species with broad ecological amplitude which is confirmed by its natural range of distribution. It is a conifer species suitable for introduction, but it is resonable to test the suitability of its provenances before introduction.

As an exotic species, Douglas-fir need to be provenance tested before introduction. Its genetics and ecological adaptability can be confirmed by the investigations of its morphologically variable characters, which is the aim of this research. For that reason, two experimental plots with twenty Douglas-fir provenances orginally from North America were established in Serbia. 
A two-way analysis of variance was aimed at a closer study of the effects of the interaction of the site conditions of Douglas-fir provenance test locations in Serbia on the morphological characters of the needles. The ANOVA results of the analyzed morphological characters of needles show that there are statistically significant differences between the provenances (Graphs 1 and 2). The LSD test shows that the provenances are homogeneous, i.e. that the differences in their mean values are not statistically significant. The lower range of character variation in these provenances, compared to others, can be conditionally considered as a consequence of their genetic similarity which conditioned similar phenotype expressions in the interaction with the external factors of the sites where the tests were established.

\section{ACKNOWLEDGEMENTS}

This paper was realized as a part of the project 'Studying climate change and its influence on the environment: impacts, adaptation and mitigation' (No. III 43007) financed by the Ministry of Education and Science of the Republic of Serbia within the framework of integrated and interdisciplinary research for the period 2011-2016.

\section{REFERENCES}

Adams, W.T., Johnson, G., Copes, D.L. and others (1990): Is research keeping up with the needs of Douglas-fir tree improvement programs? Western Journal of Applied Forestry. 5(4): 135-137.

Alexander, R.R. (1988): Forest vegetation on National Forests in the Rocky Mountain and Intermountain regions: habitat types and community types. USDA Forest Service, General Technical Report RM-162. Rocky Mountain Forest and Range Experiment Station, Fort Collins, CO: 47.

Allen, G.S. (1942): Douglas-fir (Pseudotsuga taxifolia Lamb. Britt.) A summary of its life history. B.C. For Serv. Res. Note No. 9: 27.

Allen, G.S., Owens, J.N. (1972): The life history of Douglas-fir. Environment Canada, Canadian Forestry Service, Ottawa, ON: 139.

Arno, S.F. (1990): Ecological Relationships of Interior Douglas-fir. Symposium Proceedings: "Interior Douglas-fir the species and its management." Spokane, Washington, USA.

Bialobok, S., Mejnrtowicz, L. (1970): Provenance differentiation among Douglas-fir seedlings. Arbor. Kronickie, Rocy. 15, Nadbitka: 197-219.

Campbell, R.K. (1979): Genecology of Douglas-fir in a watershed in the Oregon Cascades. Ecology 60(5):1036-1050.

Campbell, R.K. (1992): Genotype environment interaction: a case study for Douglas-fir in western Oregon. Res. Pap. PNW-RP-455. Portland, OR: U.S. Department of Agriculture, Forest Service, Pacific Northwest Research Station: 21.

Campbell, R.K., Sugano, A.I. (1993): Genetic variation and seed zones of Douglas-fir in the Siskiyou National Forest. Res. Pap. PNW-RP-461. Portland, OR: U.S. Department of Agriculture, Forest Service, Pacific Northwest R. S. 23 p.

Erikson, G., Ekeberg, I. (2001): An introduction to Forest genetics, Genetics variation and provenance research. ISBN91-576- 6032-8. SLU Reoro Uppsala 
Hermann, R.K. (1987): North American tree species in Europe. Jour. of Forestry 85 (12): 27-32.

Jovanović, B. (2000): Dendrologija. Šumarski fakultet Univerziteta u Beogradu.

Martha E. Apple, David M. Olszyk, Douglas P. Ormrod, James Lewis, Darlene Southworth and David T. Tingey (2000): Morphology and stomatal function of Douglas fir needles exposed to climate change: Elevated $\mathrm{CO}_{2}$ and temperature.International Journal of Plant Sciences. Vol. 161, No. 1 (January 2000), Pp. 127-132

Lavadinović, V., Isajev, V. (2003): Genetic diversity of Douglas-fir provenances in Serbia. International scientific conference, 75 Years of the research Institute, Bulgarian academy of sciences. Sofia, Bulgaria. Proceedings of scientific papers: 85

Lavadinović, V., Koprivica, M. (1996 a): Tracheid width of different Douglas fir (Pseudotsuga taxifolia Britt.) Provenances in test plantations in the region of Serbia. Proceedings of the 2nd International Conference on the Development of Wood Science Technology and Forestry, Sopron, Hungary: 277-286

Lavadinović, V., Koprivica, M. (1999 a): Development of young Douglas - fir stands of different provenances on oak site in Serbia. Novas Tecnologias, Editado por Ana Amaro \& Margarida Tome. Empirical and Process-Based Models for Forest Tree and Stand Growth Simulation ISBN:972-689-154-X. Deposito legal: 139925 / 99. Edicoes Salamandra, LDA Lisboa, Portugal: 231-241

Nicholas, D.Dean (1963): The influence of environment, genetics, and growth characteristics on tracheid length and specific gravity variation in a Douglas-fir provenance study. M.S. thesis. Oreg. State Univ., Corvallis: 43 p.

Rehfeld, G.E. (1989): Ecological adaptations in Douglas-fir (Pseudotsuga menziesii var.glauca): synthesis. For. Ecol and Manage. 28: 203-215.

Silen, R.R. (1978). Genetics of Douglas-fir. USDA Forest Service, Research Paper WO-35. Washington,DC, p 34.

Urbaniak L, Kalinski L, Popielarz R (2003) Variation of morphological needle characters of Scots pine (Pinus sylvestris L.) populations in different habitats. Acta Soc Bot Pol $72: 37-44$

Wright, J.W., Kung, F.H., Read, R.A., Lemmien, W.A., Bright, J.N. (1971): Genetic variation in Rocky Mountain Douglas-fir. Silvae Genet. 20 (5): 54-60

\title{
VARIABILITY OF THE WIDTH OF DOUGLAS- FIR NEEDLES IN PROVENANCE TESTS
}

\author{
Vera LAVADINOVIĆ, Vukan LAVADINOVIĆ, Zoran PODUŠKA, Milan KABILJO
}

\section{Summary}

The ecological and economic role of introduced tree species is of great significance for the forestry of Serbia. Introduction is carried out with promising species whose genetic value and potential can be confirmed after the transfer of seed into new ecosystems. Introduction of conifer species aim to ensure the same quality and productivity as in their natural environments, thus justifying the process of introduction. The effects of successful introduction require the control of genetic material and their provenance testing. In Canada and North America, Douglas-fir (Pseudotsuga menziesii / Mirb. / Franco) is one of the most important biological and economic conifer species. It is also one of the species with the widest range of natural distribution which stretches from the Pacific coast to the Rocky Mountains, New Mexico and Canada. If a species has such a wide natural range, it is important to choose the most appropriate provenance. Therefore we tested morphological 
traits of Douglas-fir needles of different provenances at two sites in Serbia. Analysis of variance and Least Significant Difference Test (LSD test) at the level of provenances within the same locality and between localities showed statistically significant differences between the sites, while the multi-factor analysis determined the impact of two factors (provenance, site) on the specific property. It was concluded that:

- within the sites, all the observed traits showed statistically significant differences in the mean values at the provenance level, which indicated that they were not caused by random, but by internal factors of the treatment; LSD test, however, pointed to the existence of several small homogenous groups for each trait, indicating lower genetic variability of the provenances that make homogeneous groups;

- $\quad$ all the properties measured at the site level show statistically significant differences with higher mean values of all measured properties at Tanda site than at Juhor site;

- There is an interaction between the factors of variability (site and provenance), i.e. a change in one variability factor causes a change in the other factor. 